\title{
Interactions between the Eurasian beaver and riparian woody vegetation along the Pechora-Volga meridian
}

\begin{abstract}
Vladimir V. Brozdnyakov
ABSTRACT. Beaver groups were examined from the dry steppe zone to the northern taiga zone from 1992 to 2014. The only region where beaver foraging activity limits the development of riparian trees and shrubs is the northern taiga, but here the effect of beaver on riparian plant communities is not critical in most settlements. However, even in the northern taiga tree forage availability is not a factor limiting the development of the beaver population. The beaver has its greatest impact on trees of preferred species and diameters. In $33.6 \%$ of settlements on the Pechora River and tributaries in the upper reaches, and in $17 \%$ of settlements in the Volosnitsa River I observed a shortage of preferred beaver foods. In the Samara lakes beavers remove two and half times the amount of woody vegetation on average compared to beavers living along the river. In $91.2 \%$ of settlements beavers removed up to $3 \%$ of the total woody plant resources per year. The trophic level base is not a factor limiting the development of the beaver population in all studied regions from the steppe zone to the northern taiga. Beaver foraging activity does not have a negative impact on plant communities, but the southern taiga woody vegetation is recovering faster than woody vegetation in the forest-steppe zone. In northern taiga beavers prefer birch with diameters up to $30 \mathrm{~cm}$ even when plentiful amounts of shrubby willows are present.
\end{abstract}

KEY WORDS: Eurasian beaver, foraging, activity, decisive impact, woody plants, development of population.

Vladimir V. Brozdnyakov [fiberrus@rambler.ru], Samara State Architecture and Construction University, Molodogvardeyskaya str. 194, Samara 443001, Russia.

\section{Взаимодействие бобров и прибрежных древостоев вдоль Печоро-Волжского меридиана}

\section{В.В. Броздняков}

РЕЗЮМЕ. С 1992 по 2014 г. обследовали группировки евразийского бобра (Castor fiber) от зоны сухих степей до зоны северной тайги. Единственный регион, где кормодобывающая деятельность бобра лимитирует развитие прибрежной древесно-кустарниковой растительности, является зона северной тайги, но и здесь влияние бобра на прибрежные фитоценозы не является решающим в большинстве поселений. Даже в зоне северной тайги дефицит древесных кормов не является фактором, лимитирующим развитие популяции. Наибольшее воздействие бобры оказывают на деревья предпочитаемых пород и диаметров. В 33.6\% поселений бобра в верхнем течении Печоры и ее притоках, а также в 17\% поселений на р. Волоснице наблюдается недостаток предпочитаемых кормов. В озерных поселениях южной части региона исследования каждый бобр в среднем изымает в два раза больше древесной растительности, чем в русловых поселениях. В подавляющем большинстве (91.2\%) поселений бобры в течение года изымают до $3 \%$ доступной древесной биомассы. Во всех исследованных зонах (от степей до северной тайги) кормовые ресурсы не являются фактором, лимитирующим развитие популяций бобра. Кормодобывающая деятельность грызунов не оказывает решающего воздействия на прибрежные фитоценозы. В зоне южной тайги восстановление древесной растительности бобром происходит быстрее, чем в лесостепной зоне. Впервые отмечены кормовые предпочтения бобров в зоне северной тайги: березы диаметра от 12 до 30 см, несмотря на значительные объемы кустарниковых ив.

КЛЮЧЕВЫЕ СЛОВА: евразийский бобр, кормодобывающая деятельность, лимитирующее воздействие, прибрежные древостои, развитие популяции. 


\section{Introduction}

Eurasian beavers (Castor fiber) actively transform their wetland habitats through tree cutting and construction behaviors. The biomass of cut trees considerably exceeds the biomass of the forage from those trees consumed by beavers. The question of how beaver foraging behavior affects forest stands is of interest as the beaver population in Eurasia continues to grow. Additionally, whether food is a limiting factor in the development of beaver colonies in various climatic zones, on different types of reservoirs, and in different plant communities is critical to understand.

My research was designed to study the interaction between populations of beavers living along river systems with the phytocenosis (plant community) in different climatic zones ranging from the dry steppe to the northern taiga.

Specifically I investigated the following:

1. The food (woody species) availability and utilization by beaver populations in the Samara, Orenburg, Tambov, Voronezh, and Kirov provinces, the Komi Republic in the territory of the Pechora-Ilych State Biosphere Nature Reserve, and in adjacent territories.

2 . The impact of beavers on the riparian phytocenosis in different types of wetlands.

3. The relationship between trophic capacity of biotopes and beaver populations.

\section{Material and methods}

Study areas. Research was conducted from 1992 to 2014 in dry steppe zone and forest-steppe zone in the Samara, Orenburg, Tambov, and Voronezh provinces. In the southern taiga zone data were collected in 2011, 2012, 2014 in the Nurgush Nature Reserve and other parts of the Kirov Province. In the northern taiga zone research was conducted between 2012-2013 in the territory of the Pechora-Ilych State Biosphere Nature Reserve and in adjacent parts of the Komi Republic. Over $3000 \mathrm{~km}$ of river and lake shoreline were investigated and more than 1300 beaver settlements were surveyed. I also investigated beaver settlements on the Saratov reservoir of the Volga River, the Samara River, Bolshoi and Malyi Kinel rivers, Sok River, lakes in a flood plain of these rivers, the Usa, Sukhaya Panda, Usman, Ivnitsa, Rostashi, Chagan, Sestra, Irtek, Bokovaya, Borovka, Koltubanka rivers, an old river area of the Vyatka River, the lake in the Vyatka basin, the Pechora River and its tributaries including the: Bolshaya Porozhnaya, Elma, Saga, Bolshoi and Malyi Shezhim, Bolshaya and Malaya Shaytanovka, Kedrovka, and Volosnitsa.

Methods. I used the ecological-statistical method of Poyarkov and Dyakov to estimate the number of beavers present in each area (Dyakov, 1975). The age structure of settlements was carried out by the morphoecological method of Fedyushin and Solovyev (see: Dyakov, 1975).
Availability and removal of woody species - trial areas. I established and studied 140 trial areas $(20 \mathrm{~m} \times$ $50 \mathrm{~m}$ in size) to examine forage availability and use. On these plots I continuously documented all trees that were growing and how beavers were used these trees. The gradation on diameter was carried out according to recalculating tables of an ecological-statistical method. The quantity of forage was converted to conventional forage units (CFU) according to the recalculating table for completely gnawed trees by beavers by application of the ecological-statistical method of Poyarkov and Dyakov (Dyakov, 1975).

The volume of woody vegetation on the trial plots in CFU was used to estimate the amount of forage available in the beaver settlement area. Removal of the woody vegetation equals the amount of vegetation in CFU that was cut by beavers. The part of the removed woody vegetation that was eaten by beavers is called 'consumed'/'utilized'. The quantity of the woody forage consumed by beavers was defined separately for individual tree species and for different diameters.

I used repeated trial areas on settlements studied the previous year to determine the influence of foraging activity by beavers on the riparian phytocenosis and the ratio of removal and regeneration of woody vegetation.

The quantity of forage in the settlement territory was defined as 'superfluous' if foraging activity by beavers did not change significantly the quantitative and qualitative structure of forest stands and regeneration of woody vegetation counterbalanced or surpassed its removal by beavers. The quantity of forage was defined as 'average', if the general amount decreased insignificantly and the structure of riparian forest changed. For example, the share of the species preferred by beavers might decrease, but there was rejuvenation of forest stands. Settlements with insufficient food are those where the foraging activity of beavers, and anthropogenous influences decreased the general quantity of woody forage by more than $10 \%$ a year and sharply decreased the quantity of the species preferred by beavers.

The consumption of woody forage was calculated by species and diameter of tree. The food availability, the size of the family site, the ratio of the beaver settlements with different forage conditions, mobility of the family, and sizes of the neutral areas (areas that are not a part of a family settlement) were studied.

All data was organized into a database and analyzed with Excel and Statistica software.

\section{Results and discussion}

Dry steppe. Settlements on the rivers Chagan, Irtek, Sestra, and Rostashi in the Orenburg Province were studied. I observed three settlements of beavers for three years at non-forested sites along the Chagan River, the inflow of the Ural River. These settlements became part of an area of intensive cattle pasture. On one of these settlements during 2011 and 2012 only 
grassy vegetation was present. In 2013 shrubby willow, which is partially consumed by beavers, started developing. On the second of these sites in 2012 all the available willow was eaten. On the third site at least $75 \%$ of the willow was consumed. However, beavers continued to live in these areas. Two more settlements had annual removal rates of 22 and $35 \%$, which surpasses vegetative renewal on an adjacent area of the river. This was also observed on three additional sites. A characteristic of all these settlements was an area of black poplar (Populus nigra) with a diameter of 20-30 $\mathrm{cm}$ located $20 \mathrm{~m}$ from the water. However, beavers were never observed using these poplars and continued to use the grassy vegetation. There was cattle pasture associated with all of these settlements. The forest density of the riparian area ranged from 0 to $20 \%$. A large number of a reeds and aquatic and grassy vegetation grew in all settlements.

Thus, in this dry steppe zone beavers systematically occupied sites without any woody vegetation and occupied these sites for years, primarily feeding on grassy vegetation.

On the forest sites in the dry steppe zone a situation similar to that in the forest-steppe zone exists. In beaver settlements willow and occasionally poplars dominate and regeneration of vegetation significantly surpasses the volume withdrawn by beavers.

Forest-steppe. Consumption of various species of trees by beavers is related to the specific structure of riparian forest stands. The main species used by beavers for food in the Samara Province is the willow - the prevailing woody and shrubby species in beaver settlements.

The number of settlements with a prevalence of willows on the Bolshoi Kinel River was $86.7 \%$, on the Sok River $85.3 \%$, and on the Samara River $89.9 \%$. On the lakes of the Samara River flood plain willow was in $57 \%$ of the settlements.

The woody species consumed by beavers along these rivers is presented in Fig. 1. On the Samara River the share of willow (from the total amount of consumed forage) in CFU is $85.6 \%$, on the Sok River the share of willow is $92.1 \%$, and on the Bolshoi Kinel River it is 99.7\%. The share of poplars (Populus nigra) utilized along the Samara River is $14.4 \%$ of the total volume consumed. On the rivers Sok and Bolshoi Kinel beavers also consume American maple (Acer negundo), alder (Alnus glutinosa) and elm (Ulmus laevis), but their consumption rate is much lower.

When examining the diameter of trees utilized by beavers in the basin of the Samara River, diameters from 2.5 to $6 \mathrm{~cm}$ are generally used. On lake settlements these diameters are $37.7 \%$ of the total amount consumed in CFU, while along the river they are $63.8 \%$.

In river settlements trees with diameters up to $12 \mathrm{~cm}$ accounted for $81.7 \%$ (this percentage includes the $63.8 \%$ of trees with a diameter from 2.5 to $6 \mathrm{~cm}$, and trees up to $2.5 \mathrm{~cm}$ in diameter and also from 6 to $12 \mathrm{~cm}$ in diameter reported above) of all consumed woody forage in CFU.

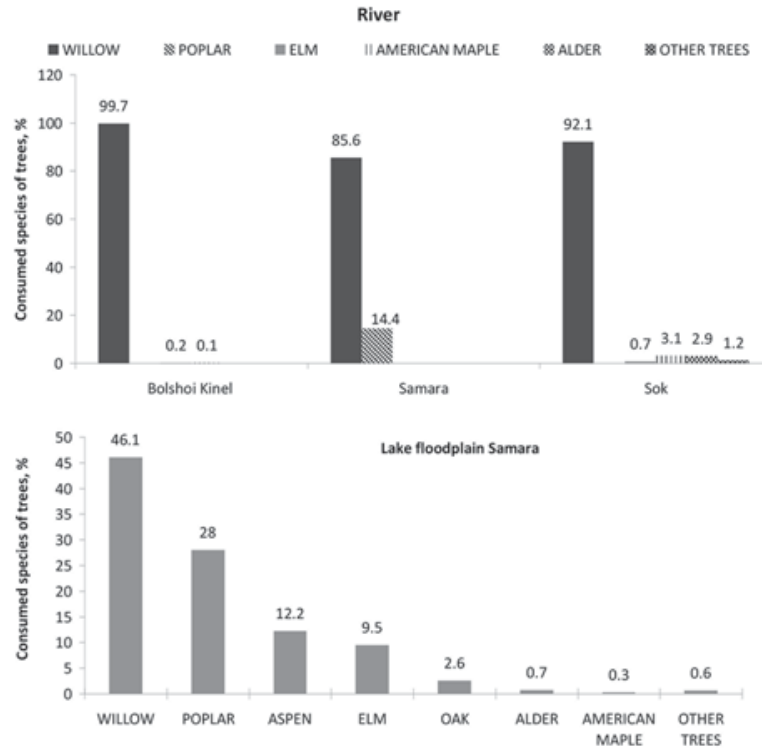

Fig. 1. Beaver consumption of woody forage by species in the forest-steppe zone (CFU, \%).

In lake settlements trees up to $12 \mathrm{~cm}$ in diameter accounted for $50.7 \%$ of the total available trees. The share of the consumed volume of trees with a diameter more than $30 \mathrm{~cm}$ is $6.4 \%$ in river settlements and $9.2 \%$ in lake settlements.

Research into the relationship between the consumption of woody species compared to the general rate of cutting showed that woody vegetation with a diameter less than $6 \mathrm{~cm}$ is almost completely consumed. The consumption percent decreases with an increase in tree diameter.

The average percentage consumed from the total amount cut in CFU (all used sterns) is $43 \%$ on lakes and $94 \%$ on the Samara River. Therefore, in lake settlements beavers are consuming significantly lower amounts of the woody vegetation they are cutting compared to beavers living along the river. The observed difference relates to the stand structure since trees with large trunk diameters prevail in the lake settlements. The percentage of their consumption is lower than the percentage of the consumption of trees with smaller trunk diameters.

The quantity of woody vegetation cut in one year by beavers in a settlement in a forest-steppe zone depended on the quantity of the food supply and the structure of the beaver family and ranged from 0.02 to $9.1 \%$. The share of settlements that cut from 0.02 to $3 \%$ of woody vegetation a year was $91.2 \%$.

The young willow shrubs, which are mainly used by beavers in the forest-steppe and the steppe, possess the ability to regenerate rapidly (Kindshy, 1985; Dvornikova, 1987). The lack of forage in beaver settlements is mostly connected with anthropogenous influences: cutting down of the riparian forest stands, intensive pastures for grazing cattle, plowing of the shoreline, or the 


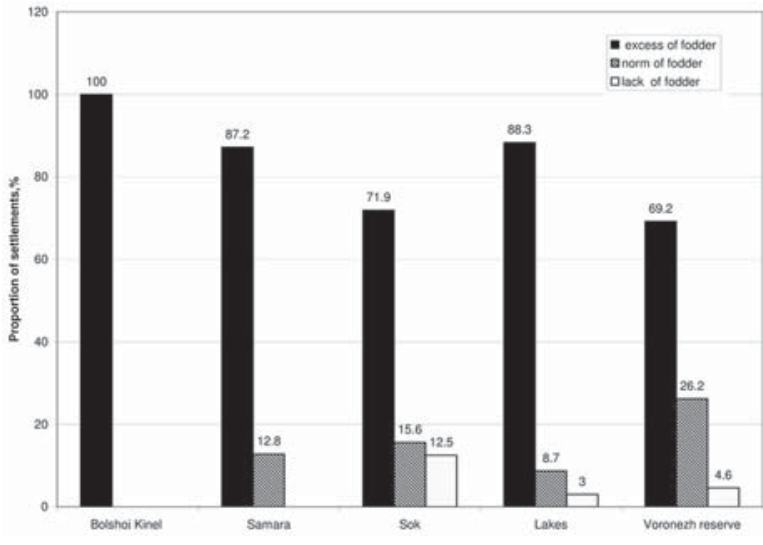

Fig. 2. Quantity of woody forage available for beavers in the forest-steppe zone.

joint influences of human activity and foraging by beavers.

In the forest-steppe zone the overwhelming a number of settlements have a surplus of woody forage (from 71.9 to $100 \%$ in different wetlands) (Fig. 2). The amount on the Voronezh Nature Reserve is slightly lower $(69.2 \%)$.

In spite of the fact that some settlements persist in one place for more than 30 years, beavers in the Samara Province never changed settlement location because of a lack of forage. Beavers were only observed using different foraging locations within their existing settlement territories. Significant changes in the general quantity of woody forage in the settlement territories described earlier in the Samara, Orenburg and Tambov provinces were not observed.

Southern taiga, Kirov Province. Trees with diameter between 20 and $30 \mathrm{~cm}$ are dominated in beaver settlements, and such settlements consists more than $80 \%$ of all settlements in the reserve and unprotected area. The consumption of trees relative to the removal of trees of various diameters in the southern and northern taiga zones was similar to that observed in the forest-steppe zone. Woody vegetation with diameters up to $6 \mathrm{~cm}$ is consumed almost completely and as the diameter increases the consumption percent decreases.

Having studied tree and shrub forage across the territory of the Nurgush Nature Reserve in 2014, I found that woody vegetation with diameters up to 30 $\mathrm{cm}$ accounted for $31.1 \%$ of the total volume consumed. Woody vegetation with diameters up to $40 \mathrm{~cm}$ accounted for $21.3 \%$ consumed and vegetation with diameters up to $6 \mathrm{~cm}$ accounted for $17.8 \%$ of the total consumed (Fig. 3). The shift in preference towards larger diameter trees is not characteristic for beavers, but probably occurred because most of the willow supply, which is usually preferred by beavers, was under water when measurements were conducted. Thus, during the summer, autumn and winter period beavers used a nearby stand of willows, while during the high water period trees of large diameter growing on higher ground were

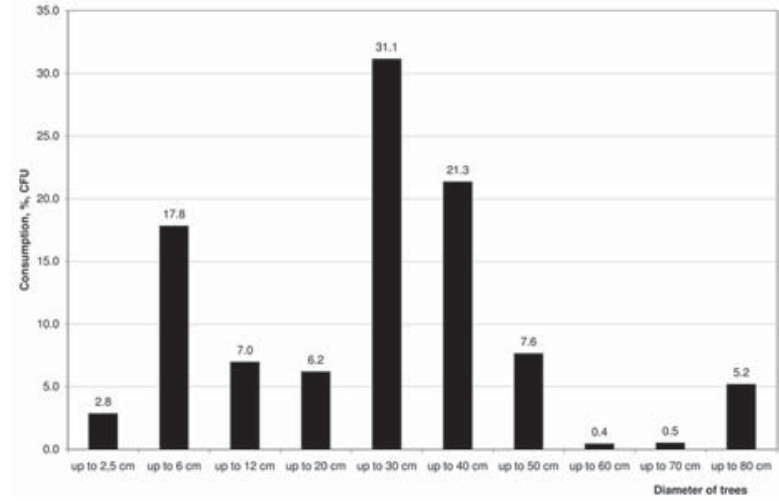

Fig. 3. Consumption of various diameters trees by beavers, southern taiga, Nurgush Nature Reserve, Kirov Province (CFU, \%).

used. Based on this I conclude that beavers use different foraging sites during a year, thus mitigating the pressure on the riparian phytocenosis. For example, in winter and late summer the shrubby willow on the main river course is used, while during periods of high water non-flooded sites with large diameter trees such as birch, oak, and linden are used.

In the Nurgush Nature Reserve, in 2014, the beavers used birch, Betula pendula, most $(27.5 \%$ of the total volume) followed by oak, Quercus robur (20.1\%), linden, Tilia cordata (18.5\%), aspen, Populus tremula $(15 \%)$, and willow, Salix caprea $(9.9 \%)$. In this region high recovery rates for trees and shrubby vegetation is characteristic. Regeneration after beaver foraging of all tree species, including oak, is pronounced.

Beavers actively consumed oak (Quercus robur) in this region, but did not have a negative impact on its growth. This is different from the situation in the foreststeppe zone where, when beavers use oak, birch renewal is strongly impacted owing to low humidity and higher anthropogenic pressure. The main competitor to beavers that impacts the regeneration of trees and shrubs in the Nurgush Nature Reserve is the elk (Alces alces). In the reserve territory $33.3 \%$ of beaver settlements were regularly used for foraging by elk (Alces alces), while in the unprotected territory $18.8 \%$ of settlements were influenced by elk foraging. In the unprotected territory wild boar (Sus scrofa) visited $12.5 \%$ of settlements, while in the reserve territory they visited 5.6\% of settlements. In general, throughout the Kirov Province, $26.5 \%$ of beaver settlements are used as foraging sites by Alces alces and $8.8 \%$ are influenced by wild boar (Sus scrofa). The fact that vegetation in a third of the beaver settlements in the reserve is under pressure from elk (Alces alces) slows the regeneration process of trees after beaver cutting.

Woody vegetation removal by beavers is significantly lower than annual renewal on the majority of settlements in the Kirov Province (both protected and unprotected zones). The maximum annual withdrawal is $3.6 \%$ of the total quantity of woody and shrubby 
vegetation in the beaver settlements of Nurgush Nature Reserve. In a number of settlements the maximum did not exceed $2 \%$ of the total woody vegetation in the settlement. The most significant beaver influence on woody vegetation occurs only along streams. On a settlement that beavers first occupied in 2011, the woody and shrubby vegetation by 2014 was almost completely utilized. The beavers removed $9.2 \%$ of the vegetation in 2011 and $13.9 \%$ in 2012 . The heavy foraging impact was due to the high number of beavers in the settlement, the small amount of aquatic vegetation present, and a narrow zone $(10 \mathrm{~m})$ of willow along the stream. Additionally, the forest density in 2011 in this settlement was only $15 \%$. In 2014 the beavers left this settlement and moved to a stream, creating three dams. The impact of beavers on the plant community of the Kirov Province (the southern taiga) was negative only in one of the 37 settlements surveyed. Regeneration rates surpassed withdrawal rates on all other settlements.

Renewal of woody vegetation in the southern taiga happens faster and more intensively than in the foreststeppe and steppe regions of the Samara and Orenburg provinces since species like birch (Betula pendula), aspen (Populus tremula) and oak suffer in the southern regions from a deficiency of moisture and high anthropogenous loading. Cases of multiple regeneration of oak (Quercus robur) in the cut area, usual in the Kirov Province, were not observed in the Samara and Orenburg provinces.

Northern taiga. Birch (Betula pendula) is the dominant tree species $(77.8 \%$ of all tree species) in beaver settlements in the Volosnitsa River area. On the Pechora River and its tributaries in the Pechora-Ilych Biosphere Nature Reserve $37.1 \%$ have birch as the dominant tree species. Fir (Picea abies) is the dominant tree species in $22.2 \%$ of settlements on the Volosnitsa River. The occurrence of more diverse forest stands is significantly higher along the headwaters of the Pechora River. Besides birch, many settlements in this area contain bird cherry Prunus padus (29.6\%), willow Salix caprea (18.5\%), fir Picea abies (11.1\%), and gray alder Alnus incana (3.7\%).

The dominant tree species in most of the settlements on the surveyed rivers of the northern taiga is birch (Betula pendula) with diameters up to $30 \mathrm{~cm}$. The share of such settlements along the Volosnitsa River is 88.8 $\%$, and on on the Pechora and upstream tributaries it is $55,6 \%$. In spite of this relative similarity there are fundamental differences in the consumption of woody species by beavers on the Volosnitsa River compared to consumption on the tributaries and the main channel of the Pechora River.

The beavers on Volosnitsa River live in a habitat that is rich in preferred tree species. Here, the main tree species consumed by beavers is aspen, Populus tremula $(45.5 \%$ of the diet). Aspen (Populus spp.), when it is present, is considered the preferred or favored tree species by both species of beavers throughout their range in the Nearctic (Busher, Hartman, 2001). Bea-

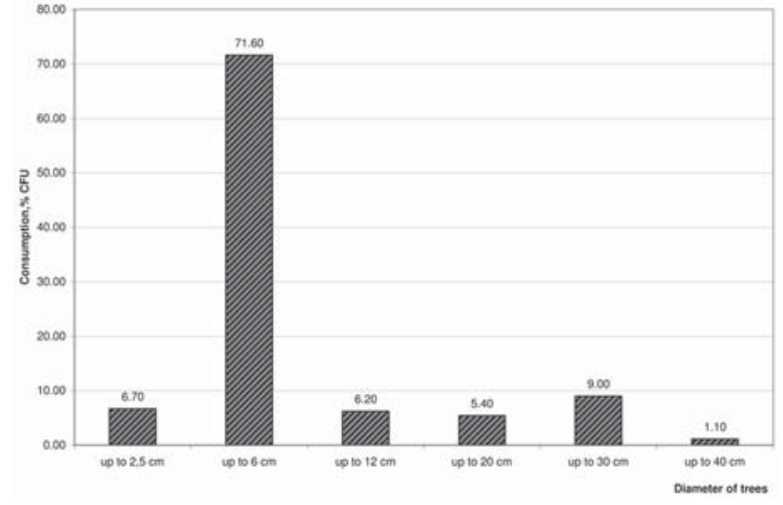

Fig. 4. Consumption of various diameters trees by beavers, Pechora River (CFU, \%).

vers also utilized large amounts of birch Betula pendula (25.5\%), and willow Salix caprea (21.4\%). Even in settlements where there were ample amounts of willow of small diameters (which is usually preferred by beavers), birch trees with diameters up to $30 \mathrm{~cm}$ were taken. The shrubby willow was not consumed or was consumed in insignificant amounts in these settlements. The use of birch is possibly due to the presence of specific nutrients or essential elements found in higher concentrations in this species. The lack of these elements in the available vegetation and in the beaver diet is due to the low quantity of aquatic grassy vegetation in this region compared to the southern region. The paucity of aquatic vegetation here is associated with the shorter vegetative period, and the lower water transparency, which is caused by a dark brown coloring in the water at this site.

A completely different situation is present on the Pechora River and reserve compared to Volosnitsa River. In spite of the fact that birch and other tree species with diameters between $20-30 \mathrm{~cm}$ dominating in the settlements, beavers consumed large quantities of willow with small diameters $(84.5 \%$ of the total, of which $78.3 \%$ are trees with diameters less than $6 \mathrm{~cm}$ ) (Fig. 4).

This is similar to other regions where, when aspen is absent, beavers prefer shrubby or small diameter $(<6$ $\mathrm{cm}$ ) willows (Fig. 5).

The majority of exiting settlements $(83 \%)$ on the Volosnitsa River have abundant and available food resources. Only $10 \%$ of beaver settlements occur in areas with a low quantity of forage species. The majority of settlements in the headwaters of the Pechora River and its tributaries have a surplus of forage available $(66.2 \%)$. Conditions of average food security occur in $28.2 \%$ of settlements, and only $5.6 \%$ live in sites that have low food availability.

A number of sites with shrubby willows (usually considered good beaver forage) are not occupied by beavers along the main channel of the Pechora River. This indicates that the trophic capacity of these sites is not the limiting factor for growth of the beaver popula- 


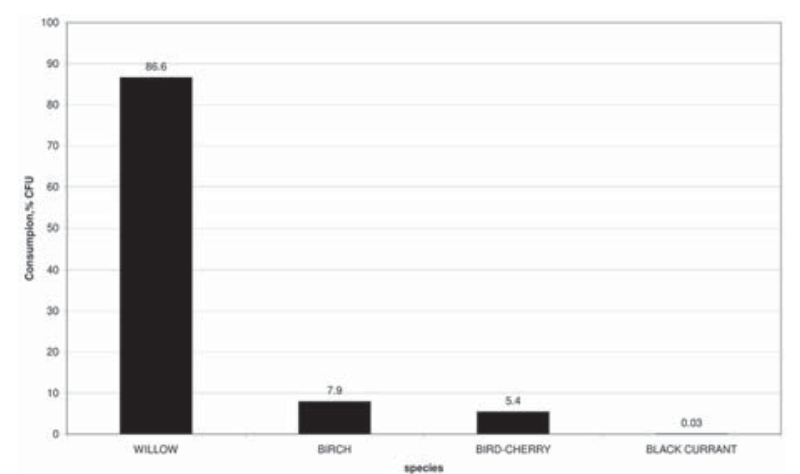

Fig. 5. Consumption of tree species by beavers, Pechora River (CFU, \%)

tion in this region. Good food security also is documented by the fact that the vast majority of settlements occupy sites not exceeding 200 meters in length in the basin of the Pechora River. The tendency to form settlements no more than $200 \mathrm{~m}$ long on sites with large supplies of woody forage was noted in the Ilmensky Nature Reserve (Dvornikova, 1987). On the Volosnitsa River this tendency is even more pronounced since the majority of beaver settlements there do not exceed 100 meters in length ( $69 \%$ of the total settlements).

In areas with low beaver densities on the Pechora River and its tributaries the presence of numerous unoccupied sites with large supplies of shrubby willows allows beavers the opportunity to move freely. In this area beavers can easily move to adjacent unoccupied territories during dispersal or if the food supply in their site becomes depleted. Beavers also have greater opportunities to choose foraging sites within existing settlements. The share of the abandoned settlements on the Pechora River is $3.7 \%$, while on tributaries it is $9.1 \%$. Similar results are observed in the Kirov Province where there are $11.8 \%$ abandoned sites. No abandoned settlements on the Volosnitsa River are registered. The low mobility of settlements testifies to favorable habitat conditions and to the high trophic capacity of biotopes (Dyakov, 1975; Fadeev, 1976; Tyurnin, 1980).

On the Pechora River, in one of the trial areas, beavers cut approximately $25 \%$ of the preferred woody species and of the preferred diameters. The removal of the preferred woody species ranges from $5 \%$ to $15 \%$ in the spring in a number of settlements on tributaries of the Pechora River. This rate, considering autumn consumption, exceeds the annual regeneration rate by many times. The impact of beaver foraging on preferred species is the limiting factor in these 12 settlements $(31.6 \%$ of the total).

\section{Conclusion}

The impact of beavers on the riparian phytocenosis is not limiting from the dry steppe to the northern taiga. Additionally, the trophic base of biotopes is not the main factor limiting the growth of beaver populations in all studied regions from the steppes to the northern taiga. Forage activity of beavers does not have a decisive impact on the forage species.

Beavers remove no more than $3 \%$ of the overall woody biomass in most of their settlements. The annual tree regeneration is about $6 \%$ in the forest-steppe areas. In the southern taiga the regeneration rate is much faster. Thus, the influence of beavers foraging and cutting activity is not a limiting factor on the forage species. Additionally, the relatively small length of the settlement areas, the relative stability of the settlement areas (long occupation durations), and the large number of unsettled areas suggest that the trophic capacity of the habitat does not limit the development of the beaver population in all regions I surveyed.

In a steppe zone beavers occupy reservoirs without any woody and shrubby vegetation present, and can live in these areas for years eating grasses. The limiting factor in the dry steppes is the water cycle of the reservoirs.

The foraging activity of beavers at a small number of settlements led to a decrease in the share of the forage species preferred by beavers and succession acceleration. In single cases beavers reduced the quantity of preferred species in the settlement area eliminating the possibility for regeneration. In these cases there were always correlated factors such as a small amount of available water, low forest density on the shoreline and high anthropogenous pressure (a cattle pasture, recreational activity, deforestation, plowing of riparian shoreline).

In lake settlements beavers removed more than twice the amount of woody species than along the river in the basin of the Samara River. The amount of woody forage removed by beavers in one year in a forest-steppe zone varied from 0.02 to $9.1 \%$. The share of settlements in which beavers removed up to $3 \%$ of the available woody forage a year was $91.2 \%$. The situation is similar in the southern taiga, but the regeneration of the woody vegetation is more rapid in the southern taiga than in the forest-steppe zone. Elk (Alces alces) impacted the vegetation in a third of the beaver settlements in the southern taiga by eating the young vegetative growth. However, in spite of the impact of elk on regeneration, the woody vegetation, after utilisation by beavers, is restored quicker here than in the foreststeppe and steppe zone.

In the Nurgush Nature Reserve during the summer, autumn and winter beavers used willow riverine bush land, while during the flood season they used largediameter trees growing on a hill away from the flooded area, resulting in reduced pressure on the riparian phytocenosis

The only region where beaver foraging activity limited the development of woody and shrubby vegetation was on a small number of settlements was the northern taiga. The percent of such settlements on tributaries of the Pechora River in the headwater area was $26.3 \%$. On the main riverbed of the Pechora River it was $7.1 \%$, and on the Volosnitsa River it was 3.8\%. The negative 
impact of beaver foraging in this region was most likely connected with the short vegetative period and small, in comparison with the southern regions, quantity of aquatic vegetation. However, the available food resource was not a factor limiting the development of the beaver population in any region including the northern taiga. The impact of beavers on the riparian phytocenosis is not the limiting factor on the majority of settlements of the Upper Pechora River basin.

The large difference between the percentages of settlements where beavers negatively impacted the woody vegetation on tributaries in reserves $(26.3 \%)$ compared to settlements along the unprotected Volosnitsa River $(3.8 \%)$ suggests that anthropogenic mechanisms (in this case hunting) reduced the beaver population (thus lowering beaver impact on vegetation) before any self-regulating mechanisms associated with beaver ecology.

Beaver foraging has the greatest impact on the preferred species. In $33.6 \%$ of beaver settlements along the Pechora River and its tributaries in headwater area, and on $17 \%$ of settlements along the Volosnitsa River the lack of the preferred forage species is observed.

Small beaver settlement size (length of shoreline occupied) and fidelity to settlement area (duration of occupation) testify to the high trophic capacity of the studied biotopes. A shift towards larger sites with shorelines more than $400 \mathrm{~m}$ long is observed on the Usman River in the Voronezh Nature Reserve (Brozdnyakov, 1998).

An interesting observation from settlements in the northern taiga was the preference by beavers for birch trees with diameters between 20 and $30 \mathrm{~cm}$ in locations with large supplies of shrubby willows. This was an unusual observation since beavers are known to use willows as a staple food resource. It may be that in this region specific nutrients in the birch influenced this foraging behavior.

Natural mechanisms of population regulation operated on the protected areas. The spatial structure and the population size are largely determined by mechanisms that work within the beaver population. Anthropogenic factors (poaching, disturbance of hydrological regime, water pollution) that reduce the number of beaver are triggered earlier than self-regulation mechanisms within the population at unprotected areas. This influence of anthropogenic factors on beaver populations was described earlier (Brozdnyakov et al., 2005). A number of authors have obtained similar results in examining the affect of hydro regime disturbance, poaching and water pollution on beaver populations.

ACKNOWLEDGEMENTS. The author expresses his sincere acknowledgments and gratitude for assistance in the investigation and work on article: V.V. Antipov, S.S. Emelyanov, O.G. Otochina, D.V. Afanasiev, A.S. Kurochkin, A.P. Martynov, A.P. Saveljev, P.E. Busher, L.V. Simakin, D.P. Strelnikov, K.V. Shestun, A.A. Skobelev, and E.S. Timonina.

\section{References}

Brozdnyakov V.V. 1998. [Ecology of Re-acclimatized Beaver Population in the Conditions of Anthropogenic Load]. Dissertatsiya Kandidata Biologicheskikh Nauk [PhD Dissertation in Zoology]. Ekaterinburg: IPAE RAS. 127 p. [in Russian].

Brozdnyakov V.V., Brozdnyakova O.G. \& Fokina M.E. 2005. [Human impact on the population of the beaver (Castor fiber L.)] // Byulleten' "Samarskaya Luka". No.16/05. P.205-213 [in Russian].

Busher P.E. \& Hartman G. 2001. Beavers // MacDonald D. (ed.). New Encyclopedia of Mammals. Oxford: Oxford University Press. P.590-595.

Dyakov Y.V. 1975. [Beavers of European Part of Soviet Union]. Moscow: Moskovskii Rabochii. 480 p. [in Russian].

Dvornikova N.P. 1987. [Population Dynamics and Biocenotic Role of Beaver in the Southern Urals]. Avtoreferat Dissertatsii Kandidata Biologicheskikh Nauk [Abstracts of PhD Dissertation in Zoology]. Sverdlovsk. 23 p. [in Russian].

Fadeev E.V. 1976. [Effect of beaver habitat on the environment] // [Trudy Voronezh State Nature Reserve]. Vol.21. No.2. P.112-116 [in Russian].

Kindshy R.R. 1985. Response of red willow to beaver use in Southeastern Oregon // Journal of Wildlife Management. Vol.49. No.1. P.26-28.

Tyurnin Y.N. 1980. [Peculiarities of population dynamics of beaver and muskrat ordinary in the Komi Republic] // [Abstracts of 5th USSR Symposium on Rodents]. Saratov. P.231-233 [in Russian]. 